\title{
Anatomy of the Underground System in Vernonia grandiflora Less. and V. brevifolia Less. (Asteraceae)
}

\author{
Adriana Hissae Hayashi ${ }^{1}$ and Beatriz Appezzato-da-Glória ${ }^{2} *$ \\ ${ }^{1}$ Seção de Anatomia e Morfologia; Instituto de Botânica; SP; C. P. 3005; 01061-970; São Paulo - SP - Brasil. \\ ${ }^{2}$ Departamento de Ciências Biológicas; Escola Superior de Agricultura "Luiz de Queiroz"; Universidade de São \\ Paulo; bagloria@esalq.usp.br; C.P. 9; 13418-900; Piracicaba - SP - Brasil
}

\begin{abstract}
This work dealt with the anatomy of the underground system in Vernonia grandiflora Less. and V. brevifolia Less. (Vernonieae; Asteraceae), two perennial geophytes, to elucidate their ability to sprout in the Brazilian Cerrado conditions. V. grandiflora, a subshrubby species, possessed a thickened underground system constituted by a xylopodium and many tuberous roots. The xylopodium had stem and root structure and its buds were axillary or originated from the cortical parenchyma proliferation. The tuberous roots produced by this organ were adventitious and accumulated inulin-type fructans mainly in the cortical parenchyma. The thickened underground system of $\mathrm{V}$. brevifolia, an herbaceous species, was a tuberous primary root whose buds originated from the proliferated pericycle. The occurrence of these bud-forming underground systems, which stored reserve compounds, enabled these plants to survive throughout unfavourable environmental conditions in the Cerrado, such as dry season and frequent fires in the winter.
\end{abstract}

Key words: Bud, tuberous root, xylopodium, fructan, Cerrado

\section{INTRODUCTION}

The Brazilian Cerrado covers approximately 2 million $\mathrm{km}^{2}$, representing about $23 \%$ of the area of the country (Ratter et al., 1997). Its flora contains a large part of the tropical biodiversity (Felfili et al., 1998) and, like that of all savannas, it is fireresistant and shows all the usual adaptations (Ratter et al., 1997), such as thick corky bark, tunicate leaf-bases in grasses, bud-forming underground organs etc (Coutinho, 1990; Jeník, 1994; Ratter et al., 1997).

The presence of underground systems, which produce buds and accumulate reserve compounds, is one of the several adaptive strategies in plants exposed to harsh conditions (Figueiredo-Ribeiro et al., 1986; Pate et al., 1990; Bowen and Pate, 1993; Bell et al., 1996). In plants from the Cerrado, the high fructan content and its variation in composition and content throughout the phenological cycle, mainly during sprouting, flowering and frutification, suggest that this carbohydrate is a reserve compound which contributes to adaptive features in plants subjected to unfavourable environmental conditions regarding to the soil, water and temperature (Carvalho and Dietrich, 1993; Figueiredo-Ribeiro et al., 1991).

The Asteraceae (Compositae) is the family more represented in this vegetation after the Leguminosae, that is, it is the second one with the major number of species (Mendonça et al., 1998).

\footnotetext{
${ }^{*}$ Author for correspondence
} 
Several representatives of this family and of others have thickened underground systems (FigueiredoRibeiro et al., 1986; Tertuliano and FigueiredoRibeiro, 1993) and due to the scarce information about their morphology and anatomy, the designation of these organs is confused (Rizzini and Heringer, 1961; Appezzato-da-Glória and Estelita 2000).

The genus Vernonia (tribe Vernonieae) contains about 500 species distributed in North and South America, tropical Africa, Madagascar and tropical Asia (Bremer, 1994). Vernonia grandiflora Less. and $V$. brevifolia Less. are subshrubby and herbaceous perennial geophytes, respectively, found in the Brazilian Cerrado. The objective of the present work was to study the anatomy of the underground system of these two species to elucidate the structural nature of these organs and also the origin of their buds relating these features to the survival of these species under Cerrado conditions.

\section{MATERIALS AND METHODS}

Plant materials were collected from natural populations in the Cerrado areas of São Paulo State, Brazil. Vernonia grandiflora Less. was collected at Fazenda Palmeira da Serra, in Pratânia ( $22^{\circ} 48^{\prime} \mathrm{S}$; 48 $\left.44^{\prime} \mathrm{W}\right)$, in December 2001, and $V$. brevifolia Less. at Reserva Biológica e Estação Experimental de Mogi Guaçu, in Mogi Guaçu $\left(22^{\circ} 18^{\prime} \mathrm{S} ; 47^{\circ} 11^{\prime} \mathrm{W}\right)$, in May 2001. Voucher specimens were deposited in the Herbarium of Escola Superior de Agricultura "Luiz de Queiroz", Universidade de São Paulo (São Paulo State, Brazil), under the numbers ESA 82474 ( $V$. grandiflora) and ESA 81071 (V. brevifolia).

Four individuals of $V$. grandiflora and two of $V$. brevifolia were examined. For the anatomical study, underground systems were fixed in FAA 50 (Johansen, 1940), dehydrated in a graded ethylic series and then embedded in glycol methacrylate resin. Serial sections (5-7 $\mu$ m thick) were cut on a rotary microtome (Sass, 1951) and stained with toluidine blue O (Sakai, 1973). Freehand crosssections were also cut and stained with astra blue and basic fuchsin (Roeser, 1972) and then dehydrated in a graded ethylic series, and 50 and $100 \%$ butyl acetate, respectively. Permanent slides were mounted in synthetic resin.

For the histochemical tests, freehand crosssections were cut from fresh material and treated with Sudan IV to detect lipidic substances (Jensen, 1962). To identify the inulin-type fructans, samples were fixed in $70 \%$ ethanol and sectioned freehand. Inulin crystals were visualized under polarized light and the presence of these crystals was confirmed by a treatment with thymolsulphuric acid reagent (Johansen, 1940).

Photomicrographs were taken with a Nikon Labophot microscope or a Nikon SMZ-2T stereomicroscope.

\section{RESULTS}

The thickened underground system of $V$. grandiflora was formed by a xylopodium and many tuberous roots (Fig. 1A). The xylopodium was an organ with a woody consistency and formed by a vertically oriented axis in the soil. This organ produced several buds distributed along the axis (Fig. 1A-E) that might develop into aerial stems. The adventitious tuberous roots were originated from this xylopodium (Fig. 1A-B).

The anatomical analyses showed that the xylopodium had a complex structure, according to the sectioning levels indicated in Fig. 1A: natural self-grafting of the bases of the stem axes at level A (Fig. 2A), stem structure (endarch xylem) at level B (Fig. 2C), transition region localized 574 $\mu \mathrm{m}$ above of the level C (Fig. 2D), and root structure (exarch xylem) at level C (Fig. 2E). The periderm covered the organ surface and enclosed the cortex and vascular cylinder (Fig. 1C). The innermost layer of the cortex, the endodermis, was conspicuous with larger cells than the cortical parenchyma cells (Fig. 2A-B). The buds originated from the self-grafting region had an axillary origin and the vascular trace reached the pith (Fig. 2A), while the buds below of this region were originated from the cortical parenchyma proliferation (Figs. 1C and 1E). 


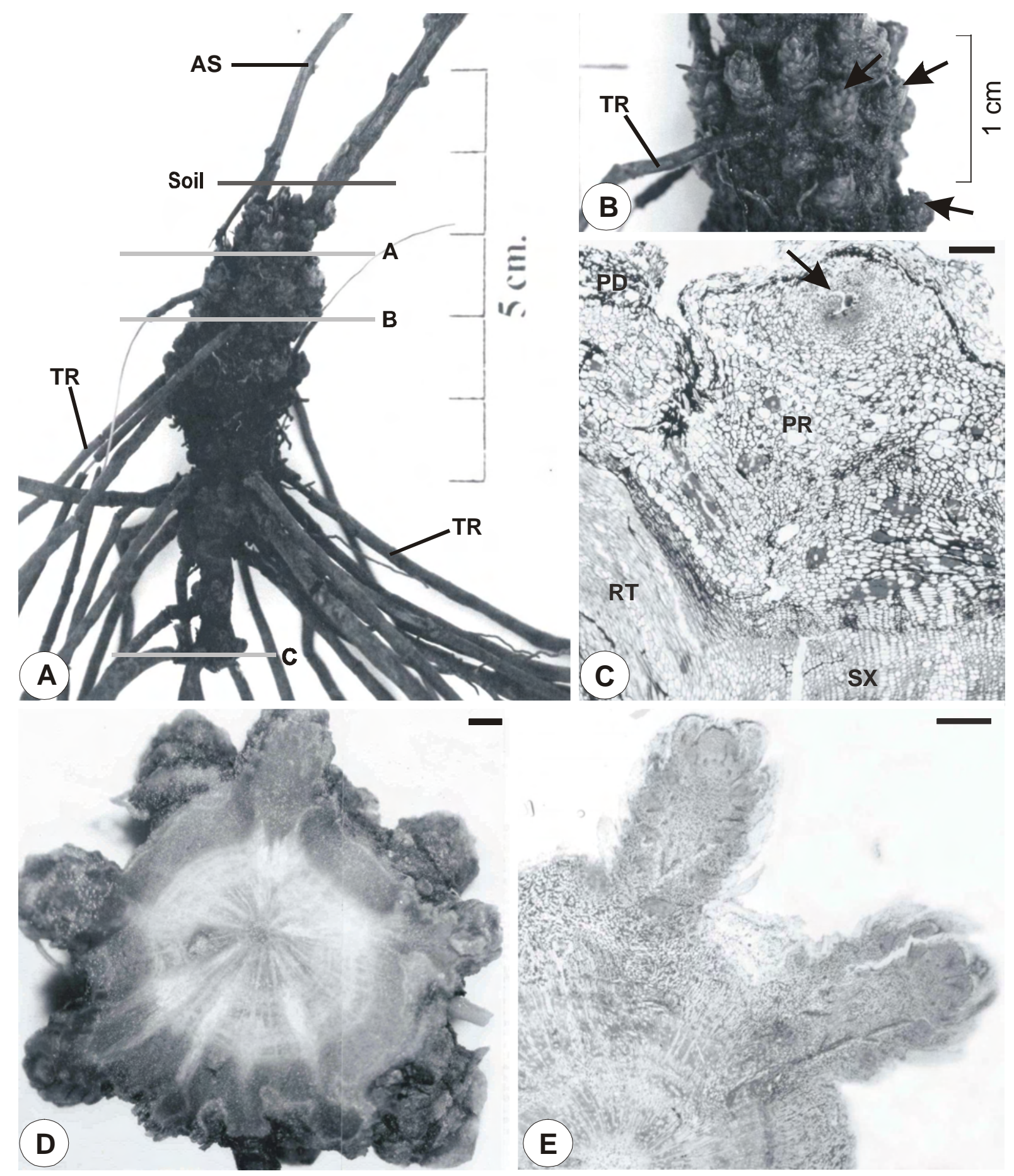

Figure 1 - Vernonia grandiflora Less. A. General view of the xylopodium showing several buds and tuberous roots. The letters $(\mathrm{A}, \mathrm{B}, \mathrm{C})$ indicate the sectioned regions which are shown in Fig. 2. B. Detail of the previous figure showing the buds (arrows). C-E. Cross-sections of the xylopodium showing the buds (arrow in Fig. C) originated from the cortical parenchyma proliferation. Bars $=200 \mu \mathrm{m}(\mathrm{C}) ; 870 \mu \mathrm{m}(\mathrm{D}, \mathrm{E})$. AS $=$ aerial stem, $\mathrm{PD}=$ periderm, $\mathrm{PR}=$ cortical parenchyma proliferation, $\mathrm{RT}=$ root trace, $\mathrm{SX}=$ secondary xylem, $\mathrm{TR}=$ tuberous root 


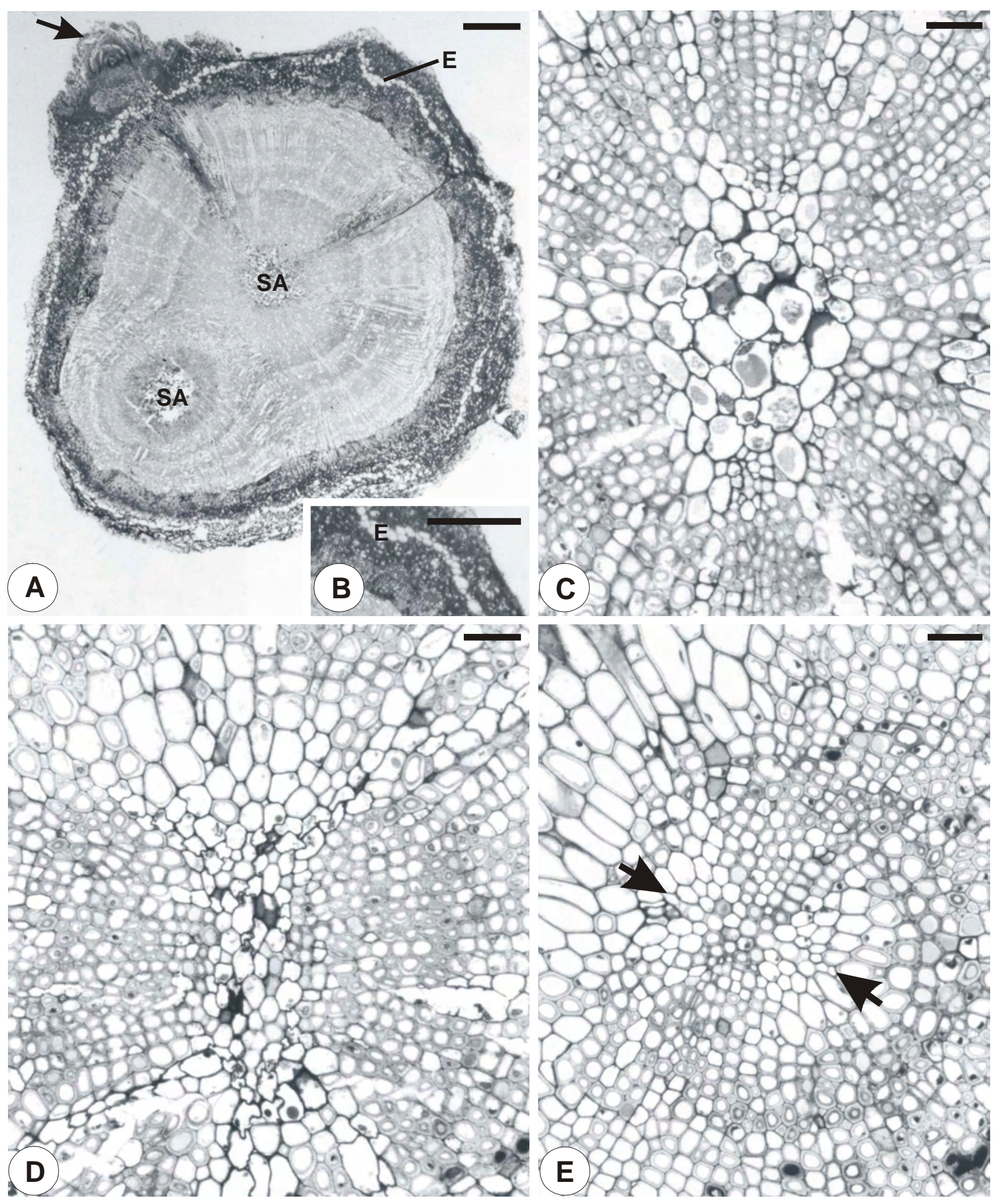

Figure 2 - Vernonia grandiflora Less. A-E. Cross-sections of the xylopodium with the sectioned regions shown in Fig. 1A. A. Natural self-grafting of the bases of two stem axes at level A. Note the conspicuous endodermis and one axillary bud (arrow) with vascular trace reaching the pith. B. Detail of the endodermis. C-E. Central region of the vascular cylinder. C. Stem structure at level B. D. Transition region. E. Root structure at level C. Note the exarch protoxylem (arrows). Bars = $760 \mu \mathrm{m}$ (A-B); $35 \mu \mathrm{m}$ (C-E). $\mathrm{E}=$ endodermis, $\mathrm{SA}=$ stem axis 

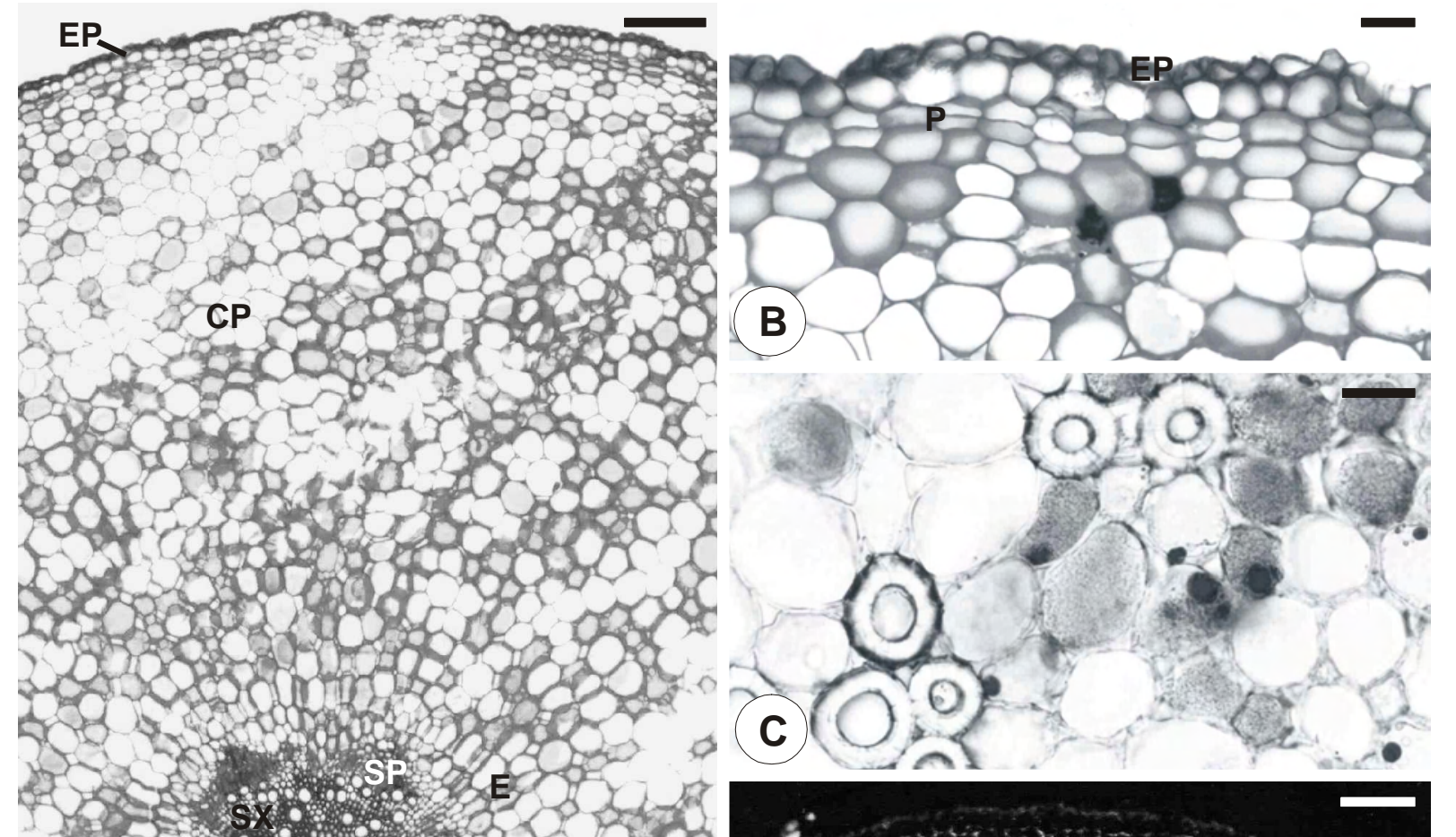

A 20.10
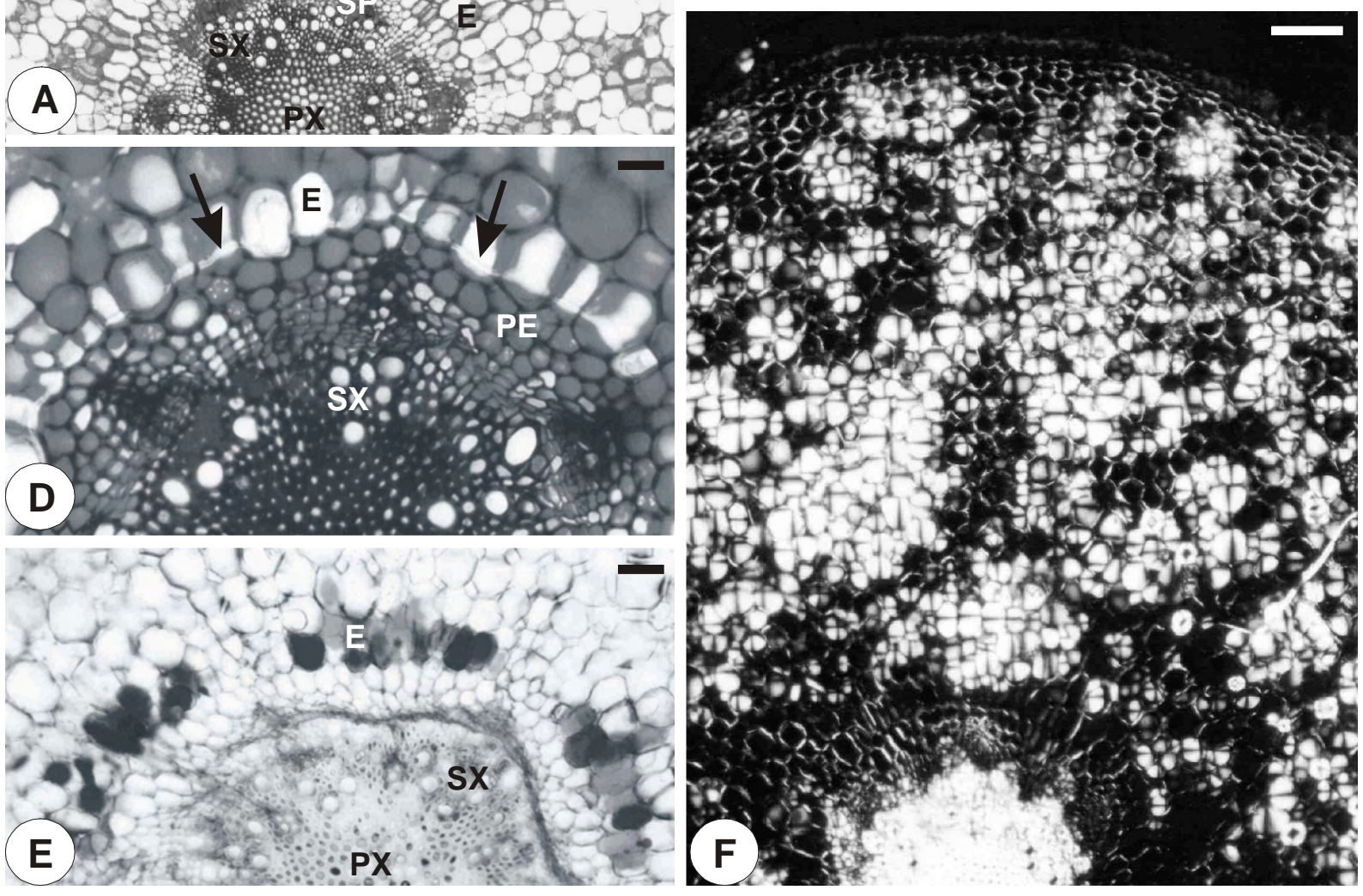

Figure 3 - Vernonia grandiflora Less. A-F. Cross-sections of the tuberous root. A. General view of the tuberous root showing the well developed cortical parenchyma. B. Formation of the phellogen from the subepidermal layers. C. Sclereids among cortical parenchyma cells. D. Endodermis with Casparian strips (arrows). E. Lipidic substances in the endodermis. F. Inulin crystals accumulated mainly in the cortical parenchyma. Bars = $200 \mu \mathrm{m}$ (A, F); $35 \mu \mathrm{m}$ (B-D); $75 \mu \mathrm{m}$ (E). CP = cortical parenchyma, $\mathrm{E}=$ endodermis, $\mathrm{EP}=$ epidermis, $\mathrm{P}=$ phellogen, $\mathrm{PE}=$ pericycle, $\mathrm{PX}=$ primary xylem, $\mathrm{SP}=$ secondary phloem, $\mathrm{SX}=$ secondary xylem 


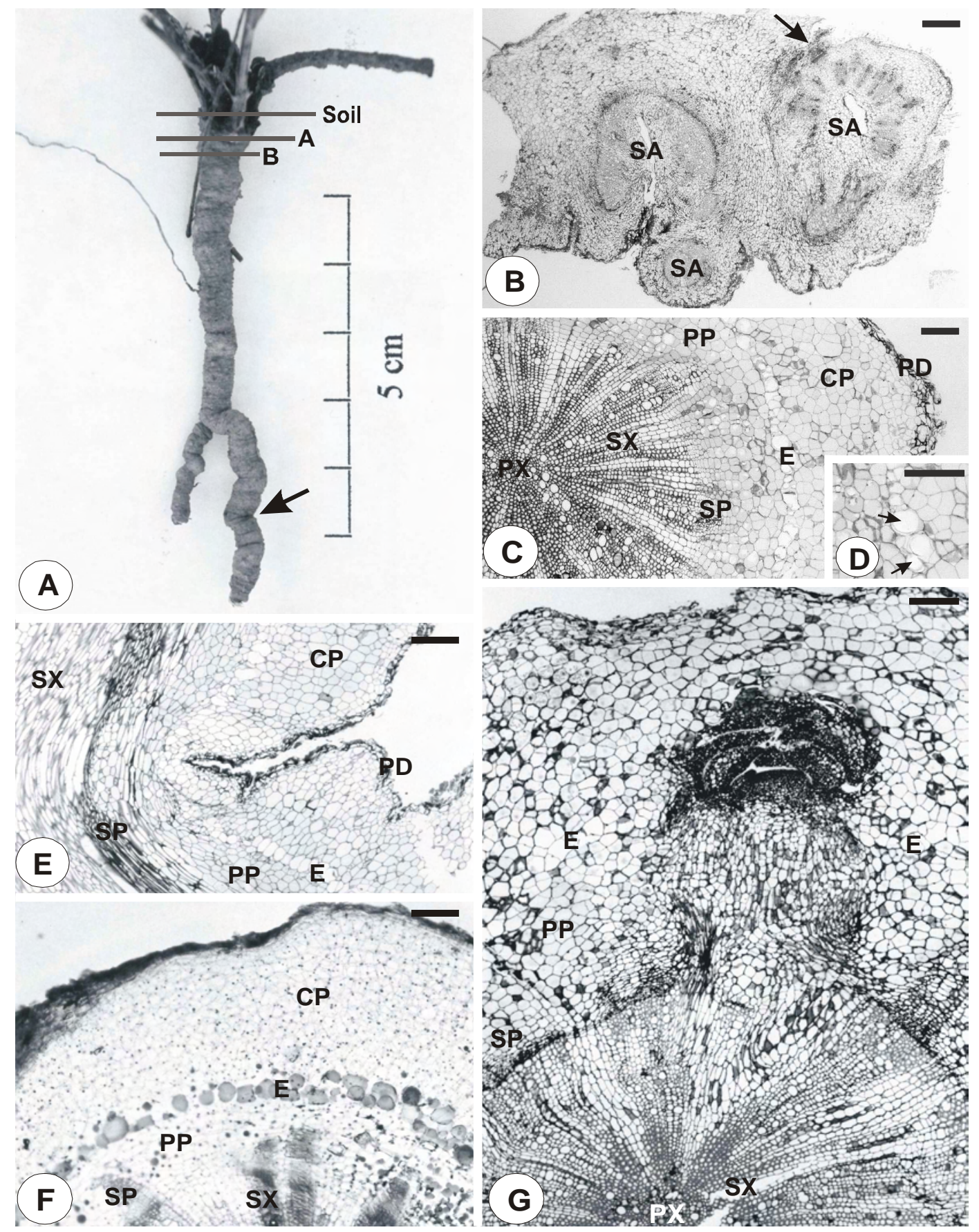

Figure 4 - Vernonia brevifolia Less. A. General view of the tuberous root. The letters (A, B) indicate the sectioned regions which are shown in Fig. 4B-C. Note a contracted area (arrow). B-C. Cross-sections of the underground system. B. Natural self-grafting of the bases of three stem axes and the presence of one axillary bud (arrow) at level A. C. Root structure at level B. D. Detail of the endodermis (arrows). E. Longitudinal section of the tuberous root. Note the contracted area shown in Fig. 4A (arrow) with a reduced number of proliferated pericycle and cortex layers. F-G. Cross-sections of the tuberous root. F. Lipidic substances in the cortical parenchyma, endodermis, proliferated pericycle, and parenchyma of secondary vascular tissues. G. Bud originated from the proliferated pericycle. Bars $=450 \mu \mathrm{m}(\mathrm{B}) ; 200 \mu \mathrm{m}(\mathrm{C}-\mathrm{G}) . \mathrm{CP}=$ cortical parenchyma, $\mathrm{E}=$ endodermis, $\mathrm{PD}=$ periderm, $\mathrm{PP}=$ proliferated pericycle, $\mathrm{PX}=$ primary xylem, $\mathrm{SA}=$ stem axis, $\mathrm{SP}=$ secondary phloem, $\mathrm{SX}=$ secondary xylem 
The adventitious tuberous roots produced by the xylopodium were covered by the epidermis (Fig. $3 \mathrm{~A}-\mathrm{B})$ and the phellogen was produced through divisions of the subepidermal layers (Fig. 3B). The cortical parenchyma was well developed and constituted by many cell layers (Fig. 3A). Sclereids occurred among these parenchymatic cells (Fig. 3C). The endodermis presented conspicuous Casparian strips (Fig. 3D) and its cells were filled with lipidic substances (Fig. 3E). The vascular cylinder was formed by the uniseriate pericycle, and the secondary and primary vascular tissues (Figs. 3A and 3D). The protoxylem had six poles and centripetal maturation (exarch xylem). Besides lipidic substances, these tuberous roots also accumulated inulin-type fructans mainly in the cortical parenchyma (Fig. 3F).

$V$. brevifolia developed a vertical, fleshy primary root as thickened underground system (Fig. 4A). This tuberous organ was contractile and its surface was irregular showing wrinkles and contraction areas (Figs. 4A and 4E). Aerial stems were produced by the upper region of the underground system and thin lateral roots were originated throughout this organ (Fig. 4A). The upper region of this thickened underground system was formed by natural self-grafting of the bases of the stem axes (Fig. 4B) between the levels $\mathrm{A}$ and $\mathrm{B}$ as indicated in Fig. 4A, and root structure (exarch xylem) (Fig. 4C) below of the level B. The periderm covered the organ surface, followed internally by the cortical parenchyma (Figs. 4C and 4E-F). In the root structure, the endodermis possessed larger cells than the cortical parenchyma cells (Fig. 4C-G) and they were filled with lipidic substances (Fig. 4F). The vascular cylinder consisted of a proliferated pericycle and secondary and primary vascular tissues (Fig. 4C).

The centre of the organ was occupied by the exarch xylem that had two protoxylem poles. As this root became thicker due to the vascular cambium activity, the cortical parenchyma and proliferated pericycle cells divided periclinally and anticlinally according to the increased diameter of the underground organ (Fig. 4C). In the contracted areas, there was a reduced number of proliferated pericycle and cortex layers (Fig. 4E), causing surface wrinkling (Fig. 4A), when compared with the non-contracted areas (Fig. 4E). Histochemical tests indicated the presence of lipidic substances in the cortical parenchyma, endodermis, proliferated pericycle, and parenchyma of secondary vascular tissues (Fig. 4F).

The buds originated from the upper region of the underground system (level A) had an axillary origin (Fig. 4B) because they were formed from the bases of the self-grafting of the stem axes, while in the root region the buds were originated from the proliferated pericycle (Fig. 4G).

\section{DISCUSSION}

The underground system of $V$. grandiflora consisted of a xylopodium and many adventitious tuberous roots while in $V$. brevifolia it was a tuberous primary root. According to Rizzini and Heringer (1961), the xylopodium has a hard and dry consistency with predominance of woody tissues while the tuberous root has a watery soft consistency with predominance of storage parenchyma as verified in both studied species. In other representatives of the genus Vernonia, the underground systems consisted of rhizophores, that is, underground stems (cotyledonary bud origin) in association with the aerial stems (plumule origin) (Menezes et al., 1979; Sajo and Menezes, 1986; Hayashi and Appezzato-daGlória, 2005). Therefore, three types of underground organs could be identified in the same genus and tribe of the Asteraceae, showing their morphological diversity.

The occurrence of xylopodia has been recorded in Brazilian Cerrado species belonging to different taxa (Appezzato-da-Glória and Estelita, 2000; Milanez and Moraes-Dallaqua, 2003), including Asteraceae representatives (Paviani, 1987, 1977). In some species, the lower portion of the xylopodium is joined to the upper portion of the tuberous root, as in Mandevilla illustris, $M$. velutina (Appezzato-da-Glória and Estelita, 2000), and Pachyrhizus ahipa (Milanez and MoraesDallaqua, 2003). As xylopodia are situated superficially in the driest soil part, they must necessarily be provided with water and food reserves in order to survive in dry seasons and to produce the aerial stems during the rainy seasons (Rizzini and Heringer, 1961). This must be the reason for which the tuberous roots were associated with the xylopodium in $V$. grandiflora as well as to the three species previously mentioned. 
The main characteristics of a xylopodium are woody consistency, ability to sprout and complex structure because of its nature (stem, root or both) (Rizzini and Heringer, 1961; Appezzato-da-Glória and Estelita, 2000). This structural complexity is also related to the process of self-grafting of stem axes (Appezzato-da-Glória and Estelita, 2000) as verified in $V$. grandiflora.

The xylopodium formation is a response to severe environmental conditions and also may be a genetically determined structure as in a tuberous root (Rizzini and Heringer, 1961). When the aerial parts of the plant are damaged by fire or die in the dry season, the underground shoot buds of the xylopodium that are well protected against overheating by the soil layer repeatedly sprout (Jeník, 1994). Thus, during the life cycle of the plant, these buds develop into aerial stems and their bases undergo self-grafting as observed in $V$. grandiflora.

The underground system of $V$. brevifolia was constituted predominantly by a tuberous primary root with small participation of stem structure (self-grafting of the bases of the stem axes). This tuberous organ showed contractile activity due to fewer number of cell layers of proliferated pericycle and cortex in contracted areas than in non-contracted areas. However, in Chlorogalum pomeridianum roots, cells of the inner and middle cortex underwent radial expansion and longitudinal shortening following contraction. Cells of the outermost cortex became distorted and collapsed whilst the stele remained relatively straight and undistorted (Jernstedt, 1984). In Trifolium repens, the root contraction was caused by the change in maturing phloem tissue, that is, there was a large proportion of air space, the fibres were shorter and distorted and the parenchyma cells were larger and more numerous in contracted area than in non-contracted area (Cresswell et al., 1999). In V. brevifolia the contraction pulled the tuberous root and its buds deeper into the ground, a process that is an adaptive mechanism to adverse environmental conditions as fire and drought in the Cerrado.

In $V$. brevifolia the buds were originated from the proliferated pericycle of the tuberous root whilst the buds of $V$. grandiflora were originated from the cortical parenchyma as described to Brasilia sickii (Asteraceae) by Paviani (1987). In Vernonia spp. (Menezes et al., 1979; Sajo and Menezes, 1986; Hayashi and Appezzato-da-Glória, 2005) and Smallanthus sonchifolius (Machado et al.,
2004) the rhizophores (cauline structure) had axillary buds.

In the tuberous roots of $V$. grandiflora and $V$. brevifolia, the presence of lipidic substances was demonstrated through histochemical tests. Hayashi and Appezzato-da-Glória (2005) also verified these substances in rhizophores of $V$. herbacea and $V$. platensis. In addition, fructans were also stored in the tuberous roots of $V$. grandiflora as showed in the present work. According to Tertuliano and Figueiredo-Ribeiro (1993), total fructans as a proportion of dry mass were $2.4 \%$ in $V$. brevifolia and less than $20 \%$ in V. grandiflora and in other species analysed in tribe Vernonieae.

Fructans have been found in thickened underground systems of Vernonia and of other Asteraceae species from the Brazilian Cerrado (Figueiredo-Ribeiro et al., 1986; Tertuliano and Figueiredo-Ribeiro, 1993; Asega and Carvalho, 2004). These carbohydrates are generally found in plants from temperate regions and then it states that fructans are related to drought tolerance (Vijn and Smeekens, 1999) and low temperature (Hendry, 1987; Vijn and Smeekens, 1999). Besides being considered as reserve carbohydrates, fructans may also act as osmotic regulators due to their rapid polymerization and depolymerization (Figueiredo-Ribeiro, 1993).

V. grandiflora and V. brevifolia are well adapted species to the Cerrado conditions because the reserve compounds in the underground organs enable the development of new shoots when the aerial parts are damaged by fire or lost during dormancy stage of the plant. These characteristics are ecologically important for the survival of these plants exposed to unfavourable conditions and this knowledge enables a suitable management of these species mainly in the disturbed areas in the Cerrado.

\section{ACKNOWLEDGEMENTS}

We thank FAPESP (Process 00/12469-3) for the financial support, CAPES and $\mathrm{CNPq}$ for the grants. We also thank Dr. M. M. Pinto, a scientific researcher at Reserva Biológica e Estação Experimental de Mogi Guaçu, Instituto de Botânica da Secretaria de Estado do Meio Ambiente - SP, for the permission granted to collect plant material for this work as well as for the field assistance. This work is part of a $\mathrm{PhD}$ thesis of Adriana Hissae Hayashi (Biologia 
Vegetal, Instituto de Biologia, Universidade Estadual de Campinas, Brazil).

\section{RESUMO}

Este trabalho teve como objetivo estudar a anatomia dos sistemas subterrâneos de Vernonia grandiflora Less. e $V$. brevifolia Less. (Vernonieae; Asteraceae), duas geófitas perenes, a fim de esclarecer sua capacidade para brotar em condições de Cerrado. O sistema subterrâneo espessado de $V$. grandiflora, uma espécie subarbustiva, é constituído pelo xilopódio e por várias raízes tuberosas. O xilopódio possui estrutura mista (radicular e caulinar) e suas gemas são de origem axilar ou se originam a partir da proliferação do parênquima cortical. As raízes tuberosas produzidas por este órgão são adventícias e acumulam frutanos do tipo inulina, principalmente no parênquima cortical. Em $V$. brevifolia, uma espécie herbácea, o sistema subterrâneo espessado é constituído pela raiz primária cujas gemas são originadas a partir do periciclo proliferado. A ocorrência destes sistemas subterrâneos gemíferos, que armazenam compostos de reserva, permite que estas plantas sobrevivam às condições desfavoráveis do Cerrado, tais como a estação seca e os frequientes incêndios durante o inverno.

\section{REFERENCES}

Appezzato-da-Glória, B. and Estelita, M. E. M. (2000), The developmental anatomy of the subterranean system in Mandevilla illustris (Vell.) Woodson and M. velutina (Mart. ex Stadelm.) Woodson (Apocynaceae). Rev. bras. Bot., 23, 27-35.

Asega, A. F. and Carvalho, M. A. M. (2004), Fructan metabolising enzymes in rhizophores of Vernonia herbacea upon excision of aerial organs. Plant Physiol. Biochem., 42, 313-319.

Bell, T. L.; Pate, J. S. and Dixon, K. W. (1996), Relationships between fire response, morphology, root anatomy and starch distribution in south-west Australian Epacridaceae. Ann. Bot., 77, 357-364.

Bowen, B. J. and Pate, J. S. (1993), The significance of root starch in post-fire shoot recovery of the resprouter Stirlingia latifolia R. Br. (Proteaceae). Ann. Bot., 72, 7-16.

Bremer, K. (1994), Asteraceae: Cladistics and Classification. Timber Press, Portland.
Carvalho, M. A. M. and Dietrich, S. M. C. (1993), Variation in fructan content in the underground organs of Vernonia herbacea (Vell.) Rusby at different phenological phases. New Phytol., 123, 735740.

Coutinho, L. M. (1990), Fire in the ecology of the Brazilian cerrado. In-Fire in the Tropical Biota, ed. J. G. Goldhammer. Springer-Verlag, Berlin, pp. 82-105.

Cresswell, A.; Sackville Hamilton, N. R.; Thomas, H.; Charnock, R. B.; Cookson, A. R. and Thomas, B. J. (1999), Evidence for root contraction in white clover (Trifolium repens L.). Ann. Bot., 84, 359-369.

Felfili, J. M.; Silva Jr, M. C.; Filgueiras, T. S. and Nogueira, P. E. (1998), Comparison of cerrado (sensu stricto) vegetation in central Brazil. Cienc. Cult., 50, 237-243.

Figueiredo-Ribeiro, R. C. L. (1993), Distribuição, aspectos estruturais e funcionais dos frutanos, com ênfase em plantas herbáceas do cerrado. Rev. Bras. Fisiol. Veg., 5, 203-208.

Figueiredo-Ribeiro, R. C. L.; Dietrich, S. M. C.; Chu, E. P.; Carvalho, M. A. M.; Vieira, C. C. J. and Graziano, T. T. (1986), Reserve carbohydrates in underground organs of native Brazilian plants. Rev. bras. Bot., 9, 159-166.

Figueiredo-Ribeiro, R. C. L.; Isejima, E. M.; DiasTagliacozzo, G. M.; Carvalho, M. A. M. and Dietrich, S. M. C. (1991), The physiological significance of fructan accumulation in Asteraceae from the cerrado. Cienc. Cult., 43, 443-446.

Hayashi, A. H. and Appezzato-da-Glória, B. (2005), The origin and anatomy of rhizophore in Vernonia herbacea and $V$. platensis (Asteraceae) from the Brazilian Cerrado. Aust. J. Bot., 53, 273-279.

Hendry, G. (1987), The ecological significance of fructan in a contemporary flora. New Phytol., 106, 201-216.

Jeník, J. (1994), Clonal growth in woody plants: a review. Folia Geobot. Phytotax., 29, 291-306.

Jensen, W. A. (1962), Botanical Histochemistry. W. H. Freeman, San Francisco.

Jernstedt, J. A. (1984), Seedling growth and root contraction in the soap plant, Chlorogalum pomeridianum (Liliaceae). Am. J. Bot., 71, 69-75.

Johansen, D. A. (1940), Plant Microtechnique. McGraw-Hill Book Co., New York.

Machado, S. R.; Oliveira, D. M. T.; Dip, M. R. and Menezes, N. L. (2004) Morfoanatomia do sistema subterrâneo de Smallanthus sonchifolius (Poepp. and Endl.) H. Robinson (Asteraceae). Rev. bras. Bot., 27, 115-123.

Mendonça, R. C.; Felfili, J. M.; Walter, B. M. T.; Silva Jr, M. C.; Rezende, A. V.; Filgueiras, T. S. and Nogueira, P. E. (1998), Flora vascular do cerrado. InCerrado: Ambiente e Flora, ed. S. M. Sano and S. P. Almeida. EMBRAPA-CPAC, Planaltina, Distrito Federal, pp. 289-556. 
Menezes, N. L.; Müller, C. and Sajo, M. G. (1979), Um novo e peculiar tipo de sistema subterrâneo em espécies de Vernonia da Serra do Cipó (Minas Gerais, Brasil). Bol. Bot. Univ. Sao Paulo, 7, 33-38.

Milanez, C. R. D. and Moraes-Dallaqua, M. A. (2003), Ontogênese do sistema subterrâneo de Pachyrhizus ahipa (Wedd.) Parodi (Fabaceae). Rev. bras. Bot., 26, 415-427.

Pate, J. S.; Froend, R. H.; Bowen, B. J.; Hansen, A. and Kuo, J. (1990), Seedling growth and storage characteristics of seeder and resprouter species of Mediterranean-type ecosystems of S.W. Australia. Ann. Bot., 65, 585-601.

Paviani, T. I. (1977), Estudo morfológico e anatômico de Brasilia sickii G.M. Barroso. II: Anatomia da raiz, do xilopódio e do caule. Rev. Bras. Biol., 37, 307324.

Paviani, T. I. (1987), Anatomia do desenvolvimento do xilopódio de Brasilia sickii G.M. Barroso. Estágio inicial. Cienc. Cult., 39, 399-405.

Ratter, J. A.; Ribeiro, J. F. and Bridgewater, S. (1997), The Brazilian cerrado vegetation and threats to its biodiversity. Ann. Bot., 80, 223-230.
Rizzini, C. T. and Heringer, E. P. (1961), Underground organs of plants from some southern Brazilian savannas, with special reference to the xylopodium. Phyton, 17, 105-124.

Roeser, K. R. (1972), Die nadel der schwarzkiefermassenproduckt und kunstwert der natur. Mikrokosmos, 61, 33-36.

Sajo, M. G. and Menezes, N. L. (1986), Origem e crescimento do rizóforo em espécies de Vernonia Screb. (Compositae) da Serra do Cipó, MG. Rev. Bras. Biol., 46, 197-202.

Sakai, W. S. (1973), Simple method for differential staining of paraffin embedded plant material using toluidine blue O. Stain Tech., 48, 247-249.

Sass, J. E. (1951), Botanical Microtechnique. Iowa State University Press, Ames.

Tertuliano, M. F. and Figueiredo-Ribeiro, R. C. L. (1993), Distribution of fructose polymers in herbaceous species of Asteraceae from the cerrado. New Phytol., 123, 741-749.

Vijn, I. and Smeekens, S. (1999), Fructan: more than a reserve carbohydrate? Plant Physiol,. 120, 351-359. 